Vol. 19 (2010): 136-143.

\title{
The effect of processing on the amino acid content in green cauliflower
}

Jacek Słupski, Zofia Lisiewska*, Waldemar Kmiecik, Piotr Gębczyński and Lidia Sobczyńska Department of Raw Materials and Processing of Fruit and Vegetables, Agricultural University of Krakow, 122 Balicka,30-149 Krakow, Poland, *email: rrlisiew@cyf-kr.edu.pl

\begin{abstract}
The aim of the work was to evaluate the level of amino acids and quality of protein in fresh green cauliflower and in three kinds of products as eaten: fresh cauliflower after cooking; and two types of frozen product: frozen cauliflower obtained using the traditional method (blanching-freezing-frozen storage-cooking); and by the modified method (cooking-frozen storage-defrosting-heating in a microwave oven). Frozen products were stored for 12 months at $-20^{\circ} \mathrm{C}$. Fresh inflorescences contained $24.32 \mathrm{~g}$ amino acids in $1 \mathrm{~kg}$ of edible parts. Expressed as g per $16 \mathrm{~g} \mathrm{~N}$ the content was $86.59 \mathrm{~g}$, with essential amino acids constituting 44\%. Culinary processing and the freezing process did not result in a drastic decrease in amino acid content apart from tyrosine. For all the samples the limiting amino acids of the first order was cystine with methionine and of the second order leucine.
\end{abstract}

Key-words: green cauliflower, amino acids, blanching, cooking, freezing, culinary treatment

\section{Introduction}

In the countries of the European Union, cauliflower occupies an important position in the production of fresh and frozen vegetables (FAOSTAT 2008). In the late 1980 s the cultivation of cauliflower with green florets was introduced in the countries of Western Europe (Vanparys 1999), and a decade later in Poland (Gajewski and Radzanowska 2003). In an investigation carried out by Gębczyński and
Kmiecik (2007) green cauliflower was found to contain more dry matter, vitamin $\mathrm{C}$, total carotenoids, beta carotene, and polyphenols than white florets; its antioxidative activity was higher; it was a good source of mineral compounds (Kmiecik et al. 2007); it did not accumulate either lead or cadmium (Lisiewska et al. 2007); and its chlorophyll content was only $15 \%$ lower than that in broccoli florets (Kmiecik et al. 2008a). Compared with white cauliflower, the raw material with green 
Vol. 19 (2010): 136-143.

inflorescences shows better storage performance (Gajewski and Radzanowska 2003) and is a more attractive material for the freezing industry since in the sensory evaluation frozen green cauliflower products achieved higher scores for colour and smell (Gębczyński and Kmiecik 2007).

Nowadays, consumers expect to obtain food products which are easy to prepare, described as "do-it-for-me" or "ready-to-eat" (Sloan 2004). Fast and simple preparation of food has been made possible by the widespread use of microwave ovens, both in the catering industry and in homes (Datta et al. 2005). The introduction to the market of this easily prepared attractive vegetable with high nutritional content increases the range of products available. Frozen green cauliflower can improve the diet of vegans since one third of its dry matter is made up of protein compounds (Souci et al. 2000).

The aim of the work was to evaluate changes in amino acid content and in the quality of protein in green cauliflower florets cooked from fresh, as well as prepared for consumption after freezing and frozen storage: obtained using the traditional technology (raw material-blanching-freezing-frozen storage-cooking in brine) and the other obtained using the modified technology (raw material-cooking in brine-freezing-frozen storage-defrosting and heating in a microwave oven), resulting in a convenience food product.

\section{Material and methods}

The investigated material consisted of green cauliflower, Trevi $\mathrm{F}_{1}$ cultivars. The evaluation concerned raw cauliflower, cooked in $2 \%$ brine and two types of frozen cauliflower prepared for consumption after 12 months of refrigerated storage at $-20^{\circ} \mathrm{C}$.

The cauliflower was grown in the experimental field of the research unit, where technological experiment was conducted, and harvested at the beginning of October. Well formed cauliflower heads were separated from stalks and divided into florets about $5 \mathrm{~cm}$ in diameter, their stalks being cut $2 \mathrm{~cm}$ below the lowest ramification. A mean sample representing the whole batch of the vegetable was taken for evaluation of raw material and of cooked material to consumption consistency in $2 \%$ brine. The cooking was carried out in a stainless steel vessel and the proportion of the raw material to brine was 1:1 weight/weight (w/w). The remaining part was divided in half; each half being processed using a different technology.

\section{Production of frozen products}

The preparation for freezing. Two variants were used in preparing the raw material for freezing. Using traditional technology (variant I) the raw material was blanched, and after freezing and refrigerated storage the frozen cauliflower needed traditional cooking. In variant II the raw material was cooked before freezing to a condition approximating to consumption consistency, hence the obtained doit-for-me product merely required defrosting and heating in a microwave oven.

In variant I cauliflower florets were blanched in a stainless steel vessel in water, the proportion of the blanched material to water being 1:5 (w/w). The blanching temperature was $95-98{ }^{\circ} \mathrm{C}$ and the time was $3 \mathrm{~min}$. and $15 \mathrm{~s}$. These conditions permitted a decrease in the activity of catalase and peroxidase to a level below $5 \%$ of the initial value. After blanching the material was immediately cooled in cold water, slightly shaken and left for 30 min on sieves to drain the water remaining on the surface.

In variant II cauliflower florets were cooked in $2 \%$ brine to a condition approximating to consumption consistency. The cooking was carried out in a stainless steel vessel and the proportion of the raw material to brine was $1: 1(\mathrm{w} / \mathrm{w})$. The cauliflower was placed in boiling water. The time of cooking measured from the moment when the medium began boiling again, to the moment the desired consistency was obtained was $6 \mathrm{~min}$. After cooking the florets were drained, placed on sieves and cooled in a stream of cold air.

The material from the blanched and cooked samples was placed on trays and frozen at $-40^{\circ} \mathrm{C}$ 
Slupski et al. Amino acids in green cauliflower

to $-20{ }^{\circ} \mathrm{C}$ in a Feutron blast freezer, type $3626-$ 51 , which was obtained inside the frozen product after $90 \mathrm{~min}$. After the desired temperature was obtained, $500 \mathrm{~g}$ portions of the cauliflower were packed in polyethylene bags suitable for the storage of refrigerated products. The bags were placed in chamber freezer at $-20^{\circ} \mathrm{C}$.

The preparation of frozen cauliflower for evaluation. Frozen cauliflower blanched before freezing was cooked in $2 \%$ brine, the proportion in weight of brine to cauliflower being 1:1 (w/w). As in the case of cooking, the material was put in boiling water. The time of cooking was 5 min measured from the moment when the brine was boiling again. After cooking the water was immediately drained and the product was cooled to $20^{\circ} \mathrm{C}$ for analyses of chemical composition.

Frozen cauliflower cooked before freezing was defrosted and a portion of $500 \mathrm{~g}$ in a heat-resisting vessel covered with a lid was heated in a Panasonic microwave type NN-F621. The time of defrosting and heating to $75^{\circ} \mathrm{C}$ was $7 \mathrm{~min} 45 \mathrm{sec}$ (Codex Alimentarius 1993).

\section{Analytical procedures}

The content of dry matter was determined by gravimetric method as the mass loss of the sample at $96-98{ }^{\circ} \mathrm{C}$ according to method 32.064 and total nitrogen $(\mathrm{N})$ according to method 2.057 described by the AOAC (1984). The content of amino acids was determined using an AAA-400 amino acid analyzer (INGOS, the Czech Republic). The analytical procedure applied was in accordance with the recommendations of the producer. The freezedried material was hydrolyzed in $6 \mathrm{M} \mathrm{HCl}$ for $24 \mathrm{~h}$ at $110^{\circ} \mathrm{C}$. After cooling, filtering and washing, the hydrolyte was evaporated in a vacuum evaporator at temperature below $50{ }^{\circ} \mathrm{C}$ for sulfur-containing amino acids and below $60^{\circ} \mathrm{C}$ for other amino acids, the dry residue being dissolved in a buffer of $\mathrm{pH}$ 2.2. The prepared sample was analysed using the ninhydrine method. Buffers of $\mathrm{pH}$ 2.6, 3.0, 4.25, and 7.9 were applied. The ninhydrine solution was buffered at $\mathrm{pH}$ 5.5. A column $370 \mathrm{~mm}$ in length was filled with Ostion ANB INGOS ionex (the Czech Republic). The temperature of the column was 55-74 ${ }^{\circ} \mathrm{C}$; that of the reactor $120^{\circ} \mathrm{C}$. The determination of the sulfur-containing amino acids, methionine and cystine, was carried out by means of oxygenating hydrolysis, using a mixture of formic acid and hydrogen peroxide $(9: 1)$ at $110^{\circ} \mathrm{C}$ for $24 \mathrm{~h}$. After cooling, the sample was processed as with acid hydrolysis. Buffers of $\mathrm{pH} 2.6$ and 3.0 were used; the temperature of the column was $60{ }^{\circ} \mathrm{C}$ and that of the reactor $120^{\circ} \mathrm{C}$. The calculations were carried out according to the external standard.

Each experiment was carried out in two replications (samples). All determinations were carried out in two replications for each experiment.

\section{Expression of results}

The level of amino acids was given in $1 \mathrm{~kg}$ of edible portion of the products in order to compare the amino acid content in green cauliflower according to the culinary and technological processing applied. The composition of amino acids was also expressed as grams per $16 \mathrm{~g}$ of $\mathrm{N}$ to estimate the quality of the protein in cauliflower by comparing it with the FAO/WHO (1991) pattern. On the basis of the amino acid composition, the chemical score index (CS) was calculated using the Mitchell and Block method (Osborne and Voogt 1978), and the integrated essential amino acids index (EAA) using the Oser (1951) method.

\section{Statistical analysis}

Statistical analysis allowing a comparison of the content of amino acids in the raw material, cooked material and frozen cauliflower after storage and preparation for consumption was carried out using single-factor analysis of variance (ANOVA) on the basis of the Duncan test, and the least significant difference (LSD) was calculated at the probability level $\alpha=0.05$ (Snedecor and Cochran 1980). The Stastica 6.1 programme was applied. 
Vol. 19 (2010): 136-143.

\section{Results and discussion}

In $1 \mathrm{~kg}$ of edible parts of raw green cauliflower, the total content of amino acids was $24.32 \mathrm{~g}$ of which essential amino acids constituted 44\% (Table 1). No data were found in the literature concerning the content of amino acids in green cauliflower, hence the point of reference was white cauliflower and broccoli. Eppendorfer and Bille (1996) reported that in white cauliflower the percentage of essential amino acids in their total content was $37-48 \%$, depending on nitrogen fertilization. According to Kmiecik et al. (2009) in broccoli florets this indica-

Table 1. Amino acid composition of raw and as eaten green cauliflower, $\mathrm{g} \mathrm{kg}^{-1}$ of edible portion.

\begin{tabular}{|c|c|c|c|c|}
\hline \multirow{3}{*}{ Amino acid } & \multirow{3}{*}{ Raw material } & \multicolumn{3}{|c|}{ Product as eaten } \\
\hline & & \multirow{2}{*}{$\begin{array}{l}\text { Cooked from } \\
\text { raw material }\end{array}$} & \multicolumn{2}{|c|}{$\begin{array}{c}\text { Prepared from frozen and stored } \\
\text { material }\end{array}$} \\
\hline & & & $\begin{array}{l}\text { Blanched before } \\
\text { freezing }\end{array}$ & $\begin{array}{c}\text { Cooked before } \\
\text { freezing }\end{array}$ \\
\hline Isoleucine & $1.02 \pm 0.14$ & $1.06 \pm 0.19$ & $1.11 \pm 0.15$ & $1.15 \pm 0.15$ \\
\hline Leucine & $1.74 \pm 0.15$ & $1.84 \pm 0.24$ & $1.91 \pm 0.27$ & $2.04 \pm 0.30$ \\
\hline Lysine & $1.75 \pm 0.21$ & $1.86 \pm 0.23$ & $1.90 \pm 0.29$ & $2.02 \pm 0.30$ \\
\hline Cystine & $0.27 \pm 0.09$ & $0.26 \pm 0.09$ & $0.25 \pm 0.08$ & $0.30 \pm 0.09$ \\
\hline Methionine & $0.32 \pm 0.11$ & $0.30 \pm 0.08$ & $0.28 \pm 0.09$ & $0.31 \pm 0.10$ \\
\hline Total sulphur amino acids & $0.59 \pm 0.21$ & $0.56 \pm 0.18$ & $0.53 \pm 0.15$ & $0.61 \pm 0.19$ \\
\hline Tyrosine & $1.41^{\mathrm{b}} \pm 0.24$ & $0.94^{\mathrm{a}} \pm 0.16$ & $0.81^{\mathrm{a}} \pm 0.18$ & $1.04^{\mathrm{a}} \pm 0.24$ \\
\hline Phenylalanine & $1.05 \pm 0.13$ & $1.10 \pm 0.10$ & $1.11 \pm 0.17$ & $1.21 \pm 0.15$ \\
\hline Total aromatic amino acids & $2.46 \pm 0.37$ & $2.04 \pm 0.25$ & $1.92 \pm 0.35$ & $2.25 \pm 0.39$ \\
\hline Threonine & $1.03 \pm 0.15$ & $1.06 \pm 0.19$ & $1.10 \pm 0.16$ & $1.16 \pm 0.15$ \\
\hline Valine & $1.43 \pm 0.20$ & $1.45 \pm 0.20$ & $1.49 \pm 0.26$ & $1.58 \pm 0.24$ \\
\hline Histidine & $0.78 \pm 0.18$ & $0.82 \pm 0.16$ & $0.85 \pm 0.20$ & $0.88 \pm 0.19$ \\
\hline Total essential amino acids & $10.8 \pm 1.59$ & $10.7 \pm 1.54$ & $10.8 \pm 1.74$ & $11.7 \pm 1.85$ \\
\hline Arginine & $1.52 \pm 0.20$ & $1.61 \pm 0.22$ & $1.63 \pm 0.24$ & $1.76 \pm 0.24$ \\
\hline Aspartic acid & $2.61 \pm 0.37$ & $2.74 \pm 0.25$ & $2.71 \pm 0.22$ & $2.95 \pm 0.27$ \\
\hline Glutamic acid & $4.26^{\mathrm{ab}} \pm 0.35$ & $4.46^{\mathrm{ab}} \pm 0.38$ & $4.10^{\mathrm{a}} \pm 0.17$ & $4.64^{\mathrm{b}} \pm 0.19$ \\
\hline Serine & $1.18 \pm 0.21$ & $1.25 \pm 0.17$ & $1.27 \pm 0.18$ & $1.34 \pm 0.19$ \\
\hline Proline & $1.43 \pm 0.23$ & $1.54 \pm 0.14$ & $1.57 \pm 0.23$ & $1.69 \pm 0.28$ \\
\hline Glycine & $1.16 \pm 0.19$ & $1.17 \pm 0.14$ & $1.19 \pm 0.16$ & $1.28 \pm 0.16$ \\
\hline Alanine & $1.36 \pm 0.11$ & $1.28 \pm 0.17$ & $1.29 \pm 0.13$ & $1.39 \pm 0.19$ \\
\hline Total non-essential amino acids & $13.5 \pm 1.59$ & $14.1 \pm 1.14$ & $13.7 \pm 1.33$ & $15.1 \pm 1.49$ \\
\hline Total amino acids & $24.3 \pm 3.13$ & $24.7 \pm 2.59$ & $24.6 \pm 3.04$ & $26.7 \pm 3.32$ \\
\hline Dry matter, $\mathrm{g} \mathrm{kg}^{-1}$ of edible portion & 93.0 & 104.6 & 92.6 & 111.3 \\
\hline Total $\mathrm{N}, \mathrm{g} \mathrm{kg}^{-1}$ dry matter & 48.3 & 47.7 & 50.6 & 48.6 \\
\hline
\end{tabular}

The data reported are means of two independent replicate analyses, each from two samples. Means in the same raw with different letters are significally different at $p<0.05$.

Means in the same raw without letters are not significally different at $p<0.05$. 


\section{AGRICULTURAL AND FOOD SCIENCE}

\section{Slupski et al. Amino acids in green cauliflower}

tor was at the level of $44 \%$ of total amino acids of $28.51 \mathrm{~g}$ in $1 \mathrm{~kg}$ edible parts. In analyzing the total amino acid content of green cauliflower florets, glutamic acid constituted $18 \%$ and aspartic acid $11 \%$. At 5-7\% were leucine, lysine, tyrosine, valine, arginine, serine, proline, glycine and alanine and at $3-4 \%$ isoleucine, phenylalanine and histidine. Total sulfuric amino acids constituted $2.4 \%$. Glutamic and aspartic acids also predominate in other vegetable species (Shou et al. 2007, Kmiecik et al. 2009, Lisiewska et al. 2008).

The cooking of fresh cauliflower did not cause significant changes in amino acid levels compared with the raw material except for tyrosine, whose content was considerably (33\%) and significantly lower. In the remaining amino acids the recorded differences varied in the range of $-6 \%-+8 \%$. The as-eaten products obtained from frozen cauliflower also differed from the raw material only in having significantly lower tyrosine content. Apart from the content of tyrosine, the percentage differences for cooked frozen product obtained using the traditional method ranged from $-12 \%$ to $+10 \%$ and for frozen product obtained using the modified method from $-3 \%$ to $+18 \%$. In edible parts of the latter product, the content of individual amino acids was $4-28 \%$ higher than in the traditional frozen product. However, after calculating the results in dry matter, the highest content of all amino acids except tyrosine was in the frozen product obtained using the traditional technology, while the lowest content of most amino acids was found in the product obtained from fresh cauliflower.

According to Ziena et al. (1991), changes in amino acid content could be affected by protein solubility in water and the destruction of the skin surface. It is possible that these changes were relative since other water-soluble compounds could also be leached, among them sugars, acids, mineral constituents and vitamins (Lisiewska et al. 2003, Słupski et al. 2004, Kmiecik et al. 2007). Changes in dry matter content (Table 1) give an indication of the extent of the above changes. For the cooked fresh cauliflower dry matter was $12 \%$ higher; for the product obtained from traditionally frozen cauliflower it was similar; and for the product obtained using the modified method it was $20 \%$ higher. This pronounced increase in dry matter content for products obtained with the use of microwave ovens has already been reported in the literature (Gębczyński 2006, Gębczyński and Lisiewska 2006).

Murcia et al. (2001) found that prolonging the time of thermal preliminary processing in water increased the loss of amino acids owing to thermal degradation. In the present investigation, thermal operations were halted, in the case of cauliflower frozen after blanching, when enzymatic activity had been sufficiently reduced and, in the case of cauliflower frozen after cooking, when, according to the sensory evaluation, consumption consistency had been achieved. The quantity of water used was also limited to the absolute minimum. DiasoluaNgudi et al. (2003) showed that losses increased with the quantity of water used as a result of diffusion. The present authors agree that changes in the level of amino acids are not only determined by the pre-treatment parameters but also by the species in question and the edible parts of the vegetable, i.e. the particular tissue under investigation (Klein and Mondy 1981, Murcia et al. 2001, Kmiecik et al. 2008b, Kmiecik et al. 2009, Lisiewska et al. 2008). The literature shows that the retention of amino acids varies depending on the factors mentioned above: statistically significant losses may be found (Candela et al. 1997, Diasolua-Ngudi et al. 2003); but also, as in the present investigation, no significant changes might be observed (Khalil and Mansour 1995, Murcia et al. 2001, El-Adawy 2002, Korus et al. 2003, Lisiewska et al. 2004); or, as reported by Mutia and Uchida (1993), the content of amino acids in edible parts may increase significantly.

The investigated samples of cauliflower were characterised by similar amounts of amino acids expressed as g per $16 \mathrm{~g} \mathrm{~N}$. Only in the case of tyrosine was a significantly lower level found in the protein of products as eaten compared with the protein in fresh cauliflower, no statistical differences being noted between the as-eaten samples. Despite the lack of statistical differences, in $16 \mathrm{~g}$ $\mathrm{N}$ of cooked fresh cauliflower the content of individual amino acids was $3-15 \%$ lower than in 16 $\mathrm{g} \mathrm{N}$ of raw cauliflower; in $16 \mathrm{~g} \mathrm{~N}$ of the product from the traditionally frozen cauliflower the chang- 
Vol. 19 (2010): 136-143.

es varied from $-16 \%$ to $+6 \%$; and in $16 \mathrm{~g} \mathrm{~N}$ of the product from the cauliflower frozen using the modified method the content was 3-19\% lower. In the case of tyrosine the respective losses were $40 \%, 44 \%$ and 38\%. Candela et al. (1997) showed more than a $50 \%$ loss of tyrosine in kidney bean during thermal processing in water. The as-eaten product which had the highest content of most amino acids was that obtained from traditionally frozen cauliflower.

During the preparation of food the side chains of some protein-bound amino acids can react chemically with each other or with other molecules present in the food (Sherr et al. 1989). Klein and Mondy (1981) deduced that heat treatments may lead to compositional changes in nitrogenous compounds depending on the mechanism of heat transfer and the particular tissue under treatment. Baxter (1995) used amino acid standards to study their behaviour in heat processes. This author showed that after treatment the level of all the amino acids was $8-14 \%$ lower except for lysine, which showed a loss of $28 \%$. In the Maillard process, which is possibly the most frequent cause of amino acid loss, the initial reaction involving sugars and amino acids is reversible. However, subsequent reactions are not reversible and amino acids are destroyed (Baxter 1995).

In the as-eaten products under investigation, the content of nitrogen changed slightly compared with the raw material. According to Lanfermeijer et al. (1989), changes in the content of nitrogen compounds due to thermal processing can be affected by their solubility in water and by possible damage to the outer tissue. It has also been claimed that the decomposition of some protein fractions rich in amino acids results in higher values of other amino acids when they are calculated on the basis of $16 \mathrm{~g} \mathrm{~N}$ (Mutia and Uchida 1993).

A comparison of essential amino acid content in the investigated samples of green cauliflower with the FAO/WHO (1991) standard showed that in all the samples the limiting amino acids of the first order were sulfuric amino acids and of the second order leucine; for these amino acids the value of the CS index was 72-84 and 89-99 respectively (Table 2). Cooking fresh vegetable and preparing frozen products for consumption after 12-months' storage brought about a similar decrease in the nutritional value of protein expressed by the value of the CS index for sulfuric amino acids, as well as variations in the level of this indicator for the

Table 2. Amino acids indexes of raw and as eaten green cauliflower according to FAO/WHO (1991).

\begin{tabular}{|c|c|c|c|c|c|}
\hline \multirow{3}{*}{ Index } & \multirow{3}{*}{ Amino acid } & \multirow{3}{*}{$\begin{array}{c}\text { Raw } \\
\text { material }\end{array}$} & \multicolumn{3}{|c|}{ Product as eaten } \\
\hline & & & \multirow{2}{*}{$\begin{array}{l}\text { Cooked from } \\
\text { raw material }\end{array}$} & \multicolumn{2}{|c|}{ Prepared from frozen and stored material } \\
\hline & & & & $\begin{array}{l}\text { Blanched before } \\
\text { freezing }\end{array}$ & $\begin{array}{l}\text { Cooked } \\
\text { before freezing }\end{array}$ \\
\hline \multirow[t]{8}{*}{$\mathrm{CS}$} & Isoleucine & 129 & 122 & 136 & 122 \\
\hline & Leucine & 94 & 89 & 99 & 91 \\
\hline & Lysine & 107 & 103 & 112 & 103 \\
\hline & Cysteine with methionine & 84 & 72 & 72 & 72 \\
\hline & Tyrosine with phenylalanine & 139 & 104 & 104 & 106 \\
\hline & Threonine & 108 & 100 & 111 & 101 \\
\hline & Valine & 146 & 133 & 145 & 134 \\
\hline & Histidine & 147 & 139 & 153 & 137 \\
\hline EAA & & 117 & 106 & 114 & 106 \\
\hline
\end{tabular}

CS - Chemical Score index

EAA - Essential Amino Acid index 
Slupski et al. Amino acids in green cauliflower

remaining essential amino acids. The highest CS index was found for histidine (137-153) and valine (133-146). The highest EAA index characterizing protein quality was registered by raw cauliflower (117), followed by the product from traditionally frozen cauliflower (114), with the lowest found in the remaining samples (106). The limiting amino acid in the protein of various vegetable species is usually methionine with cystine (Choi and Lee 1999, Diasolua-Ngudi et al. 2003, Korus et al. 2003, Kmiecik et al. 2008b), though it may also be lysine (Ishida et al. 2000, Lisiewska et al. 2004, Ayaz et al. 2006, Lisiewska et al. 2008,), histidine (Lopez et al. 1996) or tyrosine with phenylalanine (Kmiecik et al. 2009).

\section{Conclusions}

Cauliflower with green inflorescences is a good source of protein. Culinary processing and the freezing process did not result in a drastic decrease in amino acid content apart from tyrosine. The limiting amino acids of the first order for protein in both the raw material and products as eaten were methionine with cystine, and of the second order leucine.

\section{References}

AOAC. 1984. Official methods of analysis. Association of Official Analytical Chemists. 14 ed., Arlington, Virginia, USA.

Ayaz, F.A., Glew, H.R., Millson, M., Huang, S.H., Chuang, L.T., Sanz, C. \& Hayirlioglu-Ayaz, S. 2006. Nutrient contents of kale (Brasicca oleracea L. var. acephala DC). Food Chemistry 96: 572-579.

Baxter, J.H. 1995. Free amino acid stability in reducing sugar systems. Journal of Food Science 60: 405-408.

Candela, M., Astiasaran, I. \& Bello, J. 1997. Cooking and warm-holding: effect on general composition and amino acids of Kidney Beans (Phaseolus vulgaris), Chickpeas (Cicer arietinum), and Lentils (Lens culinaris). Journal of Agricultural and Food Chemistry 45: 4763-4767.

Choi, K. \& Lee, H.Y. 1999. Characteristics of useful components in the leaves of baechohyang (Agastache rugosa, O. Kuntze). Journal of the Korean Society of Food
Science and Nutrition 28: 2 326-332.

Codex Alimentarius. 1993. Code of hygienic practice for precooked and cooked foods in mass catering. CAC/ RCP 39. Cited 15 July 2008. Available on the Internet: http://www.codexalimentarius.net/web/ standard_ list.jsp.

Datta, A.K., Geedipalli, S.S.R. \& Almeida, M.F. 2005. Microwave combination heating. Food Technology 59: 36-40.

Diasolua-Ngudi, D., Kuo, Y.H. \& Lambein, F. 2003. Amino acid profiles and protein quality of cooked cassava leaves or "saka-saka". Journal of the Science of Food and Agriculture 83: 529-534.

El-Adawy, T.A. 2002. Nutritional composition and antinutritional factors of chickpeas (Cicer arietinum L.) undergoing different cooking methods and germination. Plant Foods for Human Nutrition 57: 83-97.

Eppendorfer, W.H. \& Bille, S.W. 1996. Free and total amino acid composition of edible parts of beans, kale, spinach, cauliflower and potatoes as influenced by nitrogen fertilisation and phosphorus and potassium deficiency. Journal of the Science of Food and Agriculture 71: 449-458.

FAOSTAT. 2008. Cited 15 July 2008. Available on the Internet: http://faostat.fao.org/site/567/default.aspx\#ancor

FAO/WHO. 1991. Protein quality evaluation. Report of the joint FAO/WHO Expert Consultation. FAO Food and Nutrition Paper, 51, Rome, Italy.

Gajewski, M. \& Radzanowska, J. 2003. The effect of storage on sensory quality of green cauliflower cultivars (Brassica oleracea L. var. botrytis). Vegetable Crops Research Bulletin 59: 113-120.

Gębczyński, P. 2006. Content of selected antioxidative compounds in raw carrot and in frozen product prepared for consumption. Electronic Journal of Polish Agricultural Universities, ser. Food Science and Technology 9: 3. Cited 15 July 2008. Updated 10 July 2006. Available on the Internet: http://www.ejpau.media.pl/volume9/issue3/art-03.html.

Gębczyński, P. \& Kmiecik, W. 2007. Effects of traditional and modified technology, in the production of frozen cauliflower, on the contents of selected antioxidative compounds. Food Chemistry 101: 229-235.

Gębczyński, P. \& Lisiewska, Z. 2006. Comparison of the level of selected antioxidative compounds in frozen broccoli produced using traditional and modified methods. Innovative Food Science and Emerging Technologies 7: 239-245.

Ishida, H., Suzuno, H., Sugiyama, N., Innami, S., Tadokoro, T. \& Maekawa, A. 2000. Nutritive evaluation on chemical components of leaves, stalks and stems of sweet potatoes (Ipomoea batatas poir). Food Chemistry 68: 359-367.

Khalil, A.H. \& Mansour, E.H. 1995. The effect of cooking, autoclaving and germination on the nutritional quality of faba beans. Food Chemistry 54: 177-182.

Klein, L.B. \& Mondy, N. 1981. Comparison of microwave and conventional baking of potatoes in relation to nitrogenous constituents and mineral composition. Journal of Food Science 46: 1874-1877.

Kmiecik, W., Lisiewska, Z. \& Korus, A. 2007. Retention of mineral constituents in frozen brassicas depending on the method of preliminary processing of the raw mate- 
Vol. 19 (2010): 136-143.

rial and preparation of frozen products for consumption. European Food Research and Technology 224: 573-579.

Kmiecik, W., Lisiewska, Z. \& Słupski, J. 2008a. Retention of chlorophylls in frozen brassicas prepared for consumption depending on pre-treatment before freezing. Acta Scientiarum Polonorum, ser. Technologia Alimentaria 7: 12-22.

Kmiecik, W., Lisiewska, Z., Słupski, J. \& Gębczyński, P. 2008 b. Effect of preliminary and culinary processing on amino acid content and protein quality in frozen French beans. International Journal of Food Science and Technology 43: 1786-1791.

Kmiecik, W., Słupski, J. \& Lisiewska, Z. 2010. Comparison of amino acid content and protein quality in raw broccoli and in broccoli after technological and culinary processing. Journal of Food Processing and Preservation 34: 639-652.

Korus, A., Lisiewska, Z. \& Kmiecik, W. 2003. Content of amino acids in fresh and preserved physiologically immature grass pea (Lathyrus sativus L.) seeds. European Food Research and Technology 217: 148-153.

Lanfermeijer, F.C., Koerselman-Kooij, J.W., Kollöffel, C. \& Borstlap, A.C. 1989. Release of amino acids from cotyledons of developing seeds of pea (Pisum sativum L.). Journal of Plant Physiology 134: 592-597.

Lisiewska, Z., Gębczyński, P., Kmiecik, W. \& SkoczeńSłupska, R. 2007. Effect of vegetable freezing and preparation of frozen products for consumption on the content of lead and cadmium. Polish Journal of Environmental Studies 16: 4 579-585.

Lisiewska, Z., Kmiecik, W. \& Korus, A. 2008. The amino acid composition of kale (Brassica oleracea L. var. acephala), fresh and after culinary and technological processing. Food Chemistry 108: 642-648.

Lisiewska, Z., Słupski, J. \& Zuchowicz, E. 2003. Effect of temperature and storage period on the preservation of vitamin C, thiamine and riboflavin in frozen dill (Anethum graveolens L.). Electronic Journal of Polish Agricultural Universities, ser. Food Science and Technology 6: 2. Cited 15 July 2008. Updated 01 September 2003. Available on the Internet: http://www.ejpau.media.pl/ volume6/issue2/food/art-07.html.

Lisiewska, Z., Słupski, J., Kmiecik, W. \& Gębczyński, P. 2004. Amino acid profiles and protein quality of fresh and frozen dill depending on usable part of raw material, pre-treatment before freezing and storage temperature of frozen products. Electronic Journal of Polish Agricultural Universities, ser. Food Science and Technology 7: 1. Cited 15 July 2008. Updated 01 March 2004.
Available on the Internet:

http://www.ejpau.media.pl/ volume7/issue1/food/art-03. $\mathrm{html}$.

Lopez, G., Ros, G., Rincon, F., Ortuno, J., Periago, M.J. \& Martinez, M.C. 1996. Amino acids and in vitro protein digestibility changes in green asparagus (Asparagus officinalis, L.) during growth and processing. Food Research International 29: 617-625.

Murcia, M.A., Lopez-Ayerra, B., Martinez-Tome, M. \& Garcia-Carmona, F. 2001. Effect of industrial processing on amino acid content of broccoli. Journal of the Science of Food and Agriculture 81: 1299-1305.

Mutia, R. \& Uchida, S. 1993. Effect of heat treatment on nutritional value of winged bean (Psophocarpus tetragonolobus) as compared to soybean I. Chemical characteristics of treated winged bean. Asian-Australian Journal of Animal Science 6: 19-26.

Osborne, D.R. \& Voogt, P. 1978. The analysis of nutrients in food. Academic Press: London UK.

Oser, B.L. 1951. Method for integrating essential amino acid content in the nutritional evaluation of protein. Journal of American Dietetic Association 27: 396-399.

Sherr, B., Lee, M. \& Jelesciewicz, C. 1989. Absorption and metabolism of lysine Maillard products in relation to utilization of L-lysine. Journal of Agricultural and Food Chemistry 37: 119-122.

Shou, S., Lu, G. \& Huang, X. 2007. Seasonal variations in nutritional components of green asparagus using the mother fern cultivation. Scientia Horticulturae 112: 251-257.

Sloan, A.E. 2004. New rules for ready to eat. Food Technology 58: 2, 16.

Słupski, J., Lisiewska, Z. \& Kmiecik, W. 2004. Effect of usable parts of dill and of preliminary processing on the quality of frozen products depending on the time and temperature of storage. Acta Scientiarum Polonorum, ser. Technologia Alimentaria 3: 67-75.

Snedecor, G.W. \& Cochran, W.G. 1980. Statistical methods. 7 ed. lowa State University Press: Ames, lowa, USA.

Souci, S.W., Fachmann, W. \& Kraut, H. 2000. Food composition and nutrition tables. Medpharm Scientific Publishers, Stuttgart, Germany.

Vanparys, L. 1999. Alternative cauliflowers. Green, purple or romanesco: what are the possibilities? Proeftuinnieuws 9: 27-28.

Ziena, H.M., Youssef, M.M. \& El-Mahdy, A.R. 1991. Amino acid composition and some antinutritional factors of cooked faba beans (Medammis): Effects of cooking temperature and time. Journal of Food Science 56: 1347-1352. 